\title{
Reward Administration System Enhancing Organizational Commitment: An Islamic Viewpoint
}

\author{
Azman Ismail1*, Aimi Anuar², Mohamad Sabri Haron³ \\ Razaleigh Muhamat Kawangit ${ }^{4}$ \\ ${ }^{1}$ Faculty of Economics \& Management, Universiti Kebangsaan Malaysia, \\ 43600 Bangi, Selangor, Malaysia \\ 2Islamic Hadhari Institue, Universiti Kebangsaan Malaysia, \\ 43600 Bangi, Selangor, Malaysia \\ ${ }^{3}$ Centre for General Studies, Universiti Kebangsaan Malaysia, \\ 43600 Bangi, Selangor, Malaysia \\ ${ }^{4}$ Faculty of Islamic Studies, Universiti Kebangsaan Malaysia, \\ 43600 Bangi, Selangor, Malaysia \\ *E-mail address: azisma08@gmail.com¹, aimianuar@gmail.com², sabrie@ukm.my³, \\ raza@ukm.my4
}

\begin{abstract}
This aim of this study is to examine the relationship between reward administration system and organizational commitment. A survey method was employed to gather self-report questionnaires from employees in Malaysian private institutions of higher learning. The outcomes of SmartPLS path model analysis showed two important findings: first, communication was positively and significantly correlated with organizational commitment. Second, participation was positively and significantly correlated with organizational commitment. This result demonstrates that the reward administration system does act as an important predictor of organizational commitment in the studied organizations. Further, this study provides discussion, implications and conclusion.
\end{abstract}

Keywords: Communication; participation; organizational commitment

\section{INTRODUCTION}

Reward is a multidimensional concept and may be interpreted based on language, Islamic and organizational perspectives. In Islamic dictionaries, reward is also called as ujrah where Allah SWT will bestow mukafaah (positive rewards/incentives) and jannah (paradise) to individuals who obey Him (Oxford Dictionary of Islam, 2004). Conversely, Allah SWT will provide qasas (negative rewards/punishment) and jahim (hell) to individuals who do not obey Him.

This issue is clearly stated in the Qur'an as: "Allah does not charge a soul except [with that within] its capacity. It will have [the consequence of] what [good] it has gained, and it will bear [the consequence of] what [evil] it has earned. "Our Lord, do not impose blame upon 
us if we have forgotten or erred. Our Lord, and lay not upon us a burden like that which You lay upon those before us. Our Lord, and burden us not with that which we have no ability to bear. And pardon us; and forgive us; and have mercy upon us. You are our protector, so give us victory over the disbelieving people". (Surah Al-Baqarah 2:286).

Moreover, for each good thing that a person carries out in this world will be positively rewarded by Allah SWT as mentioned in the Qur'an: "And those who believe and do righteous deeds, We will surely remove from them their misdeeds and will surely reward them according to the best of what they used to do". (Surah Al-Ankabut 29:7). Prophet Muhammad PBUH also highlighted that: "Pay the worker for his work before his sweat dries" (Ibn Majah, 1975) and "Prohibited from taking someone to work until notified rates of wages" (Ibn Ahmad, 1978).

Based on the Qur'an and hadith (words/behavior of Prophet Muhammad PBUH), the notion of ujrah (financial compensation for services) and uruf (customary by syariah) has been adapted by contemporary management scholars and practitioners as an important issue in human capital management. Under this view, reward is generally defined as an individual given something in recognition of service, effort or achievement (Oxford English Dictionary, 2007; Kamus Dewan, 2000). Specifically, the reward system is often related to reimbursement where an employer gives most focus on planning, organizing, leading and controlling nonmonetary rewards (e.g., salary and bonus) and monetary rewards (e.g., leave, loan, health treatment and service related benefits) to bestow its employees who able to perform work or service in organizations (Henderson, 2009; McShane \& Von Glinow, 2005).

Many employers have designed reward administration system based on internal alignment and external competitiveness variables. Internal alignment is often related to internal organizational variables like corporate strategy, management philosophy, type of job and level of productivity. While, external competitiveness usually refers to external organizational variables such as economic pressures, government policies, laws and regulations, as well as stakeholders cultures and customs (Milkovich \& Newman, 2010; Singh $\&$ Agarwal, 2002). These variables strongly motivate employers to design and administer the various types of reward system based on job and/or performance. Even though the design of reward for both criteria is important, it will not be able to motivate employees performing the organizational strategic mission if its reward system is not well-administered (Milkovich \& Newman, 2010; Appelbaum, Baily, Berg \& Kallerberg, 2000; Henderson, 2009; Ismail \& Zakaria, 2009).

A review of current literature pertaining on Islamic reward system highlights that the effective reward administration system has two salient components: communication and participation. Caliph 'Umar illustrated these components, thus: "There is no Islam without a group holding fast with its message, and there is no group without leadership and no leadership without obedience". (Ahmed Ibrahim, 1981). In a Quran, communication is generally defined as relationship between sender and receiver based on Qaulan principle (Azman et al, 2010; Rizal, 2009). This principle is described at several places in the Quran like Qaulan Sadida (Surah Fussilat 41:33, al-Najm 53:3-4, Ibrahim 14:27 -decisive and true words), Qaulan Ma'rufa (Surah Luqman 31:16-19, al-Baqarah 2:83 -good words), Qaulan Baligha (surah al-Maidah 5:1, al-An'am 6:115 -words that fulfilled the promise), Qaulan Masyura (Surah al-Isra' 17:53 -the words of a good and fast), Qaulan Karima/Tayyibah (Surah Ibrahim 14:24-25 -noble words) and Qaula Layyina (Surah al-nahl 16:125, Taha 20: 44 -said a gentle word). The significance of communication is stressed in Qur'an (Surah AlImran 3:110) which stated that the Prophet Muhammad PBUH and his followers are informed that they are being assigned the guidance and leadership of the world. 
Hence, the notion of Qaulan based communication has been adapted in managing the workplace reward system. In a compensation management perspective, communication is often defined as a delivery of information from employees to the organization and from the organization to employees (Fitzgerald, 2000; Hewitt Associates, 1991). Communicating reward information from employees to the organization refers to reward administration analysts, human resource management experts/pay specialists working together with stakeholders to actively seek broad information (e.g., job information, labor market information, performance information, organizational economic capabilities, and legal requirements) and specific information (e.g., compensation expectations, benefits preferences, administrative preferences and employee equity perceptions) from employees (Henderson, 2000; Milkovich \& Newman, 2010; Lawler, 1995b).

Conversely, communicating pay information from the organization to the employees refers to the amount of reward information that can be disseminated from the organization to employees will depend on its policy. For example, in a communication openness policy, administrators will clearly expose the value of reward and permit employees' voices in managing reward systems. While, in a communication secrecy policy, administrators will decide or control which suitable information should be openly delivered to employees. These communication policies are often used by administrators to enhance employees' understanding about the policy and procedures of reward system, avoid feelings of inequity, to2000; Henderson, 2000).

Participation is generally defined as individuals are obligated to cooperate each other in performing amar makruf nahi munkar (Surah At- Taubah 9:71). The significance of participation is also stressed in the Qur'an (Surah Al-Imran 3:110), in view of the task entrusted to the Muslims, they had to become conscious of their responsibilities and avoid the mistakes committed by their predecessors. Thus, the Muslims were charged with this responsibility because of their competencies in collaborative perspectives (Surah Al-Baqarah 2:143).

The notion of Quran based participation has been adapted to manage workplace reward system. In a compensation management perspective, participation in reward systems is usually defined as the involvement of employees from different hierarchy levels and categories in the design and administration of pay designs (Belfield \&Marsden, 2003; Kim, 1996 \& 1999; Lee et al., 1999). Involvement in pay design refers to employees who are given more opportunity to provide ideas in establishing the various kinds of pay systems to achieve the major goals of its systems, stakeholder's needs and/or organizational strategy (GomezMejia \& Balkin, 1992a \& 1992b; Lawler et al., 1993). While, involvement in pay administration refers to employee involvement in providing suggestions to determine the enterprise's goals, resources and methods, as well as allowing employees to share the organization's rewards in profitability and/or the achievement of productivity objectives (Coyle-Shapiro, Morrow, Richardson \& Dunn, 2002; Kim, 1996 \& 1999). These participation styles will encourage management and employees to be honest in making personal contributions and support the workplace reward administration program (Colquitt, Conlon, Wesson, Porter \& Ng, 2001; Robbins, Summers, Miller \& Hendrix, 2000).

Extant studies about the workplace compensation management reveal that the ability of administrators to appropriately implement communication and participation styles in administering the various types of reward system may have a significant impact on employee attitudes especially organizational commitment (Bhakta \& Nagy, 2005; McClausland, Pouliakas \& Theodossiou, 2005). In an Islamic perspective, organizational commitment is 
often defined as work should be a duty shared between the employer and the employee (Surah Al-Maidah: 1), both of them should be concerned with the existence and continuation of the organization for which they work as the owner. Furthermore, the Muslims who believe and practice Islam are more committed to their organizations than non-believers of religion (Yousef, 2001). Based on the hadith, the Prophet Muhammad PBUH said if a Muslim follower trusts a Muslim leader with his affairs, and the leader does not attempt to benefit the trustee materially or morally then he will not go to heaven (Beekun \& Badawi, 2004).

In an organizational behavior perspective, organizational commitment is generally interpreted as an employee is attached to his/her organization. Specifically, it may be defined as an employee's belief in the organization's goals and values, a desire to remain a member of the organization and loyalty to the organization (Mowday et al., 1982; Hackett et al., 2001; Maume, 2006).

Within the workplace reward system model, many scholars think that communication, participation and organizational commitment are distinct, but highly interrelated constructs. For example, the ability of managers to openly communicate the information about reward systems and actively participate in reward systems may lead to greater organizational commitment in organizations (Ismail et al., 2007; Shaw, Duffy, Jenkins \& Gupta, 1999). Even though the nature of this relationship is interesting, the effectiveness of reward management system as an important predicting variable gives less attention in the workplace reward system research literature (Ismail et al., 2007; Shaw, Duffy, Jenkins \& Gupta, 1999).

Many scholars argue that the predicting variable of the reward administration system is given less attention in the previous studies because they have over discussed on the internal features of the reward administration system, employed a simple correlation method to describe employees' reactions toward the types of the reward administration system, and ignored to measure the effect of the reward administration system on employee outcomes in the workplace reward system models. As a result, these studies have not provided adequate findings to be used as guidelines by practitioners in understanding the complexity of the reward administration system and designing suitable strategic action plans to enhance the effectiveness of the reward administration system in the agility organizations (Theodossiou \& Zangelis, 2009; Wilkens \& Nermerich, 2011). Thus, it motivates the researchers to further explore the nature of this relationship.

\section{PURPOSE OF THE STUDY}

This study has two primary objectives: first, is to assess the association between communication and organizational commitment. Second, is to assess the association between participation and organizational commitment. The structure of discussion in this paper is as follows: first, theoretical and empirical evidence are provided to support the association between the variables of interest. Second, the SmartPLS version 2.0 was employed to determine the validity and reliability of instrument and test the research hypotheses. Finally, discussion, implications and conclusions are elaborated. 


\section{LITERATURE REVIEW}

An administration system based on different samples like perceptions of 170 employees from telecommunication organizations of Pakistan (Zeeshan, Hina, Nadeem \& Ebtisam, 2010), perceptions of 333 Malaysian middle and top level managers in the private sector (Sharan \& Garib, 2009) and 553 non-managerial employees in Omaha, the largest city in the state of Nebraska, United States (Hafer \& Martin, 2006). The outcomes of these studies reported two important findings: first, the ability of administrators to openly communicate the information about reward systems (e.g., open discussion, better explanations, and negotiation) had been an important predictor of organizational commitment in the respective organizations (O'Malley.M, 2000; Mignerey.J, et al., 1995). Second, the ability of administrators to encourage employees to actively participate in reward systems (e.g., participation in decision making) had been an important predictor of organizational commitment in the different organizations (Zeeshan et al., 2010; Sharan \& Garib, 2009; Hafer \& Martin, 2006).

The research literature is consistent with the notion of organizational behavior theory. For example, Lawler (1971) discrepancy theory posits that determination of pays equally with employee's expectation (e.g., contribution/effort) may enhance positive individual behavior. Besides that, Vroom's (1964) expectancy theory proposes that an employee will decide to behave or act in a certain way due to what he/she they expect the result of that selected decision. Application of these theories in a reward administration model shows that individuals will perceive fairness about outcomes and understand about the value of outcome if management able to properly implement communication and participation in the administration of reward systems. As a result, it may lead to greater organizational commitment (Zeeshan et al., 2010; Sharan \& Garib, 2009; Hafer \& Martin, 2006; O’Malley, 2000; Mignereyet al., 1995). The literature has been used as foundation to propose a conceptual framework as illustrated in Figure 1.

Independent Variable $\quad$ Dependent Variable

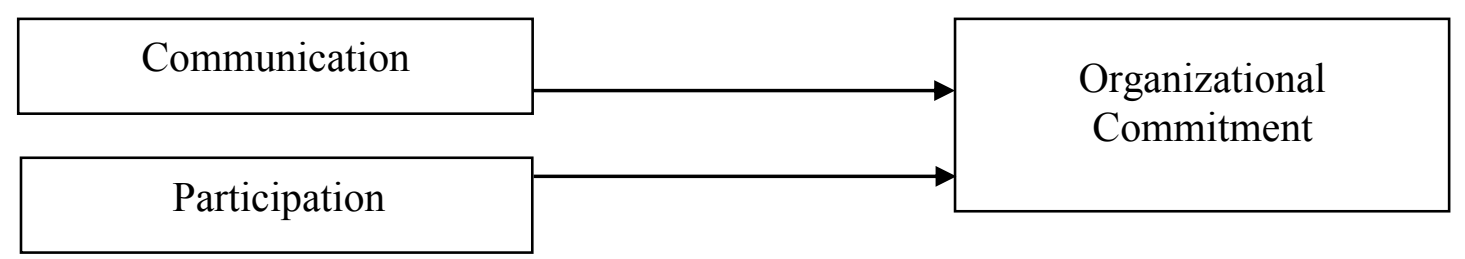

Figure 1. Conceptual Framework.

Based on the literature, it can be hypothesized that:

H1: There is a positive relationship between communication about reward systems and organizational commitment

H2: There is a positive relationship between participation in reward systems and organizational commitment 


\section{METHODOLOGY}

This study employs a cross-sectional research design that allows the researchers to combine the performance based reward literature, the pilot study and the actual survey as a main procedure to gather data for this study. Using this procedure may increase the ability to gather accurate data, decrease bias data and increase the quality of data being collected (Cresswell, 1998; Sekaran \& Bougie, 2010). The context of this study is private tertiary educational institutions in Peninsular Malaysia. In order to maintain reputation, the name of this organization is kept anonymous in order to maintain their reputations.

At the initial stage of data collection, the researchers had drafted the survey questionnaires based on the related literature review. After that, the pilot study was conducted by discussing the questionnaires with 20 administrations and academic employees in the Malaysian institutions of higher learning. A purposive sampling technique was used to select the employees because they were having working experiences from 10 to 20 years and showed good knowledge and experience about the management of compensation programs in their organizations. The information gathered from this pilot study helped the researchers to improve the content and format of the survey questionnaires for an actual study. A back translation technique was used to translate the survey questionnaires into English and Malay languages in order to increase the validity and reliability of research findings (Cresswell, 1998; Sekaran \& Bougie, 2010).

The survey questionnaire used in this study had two sections. Firstly, communication about reward systems had 4 items and participation in reward systems had 5 items adapted from reward management literature (Greenberg, 2003; Milkovich \& Newman, 2007; Pettijohn, et al., 2001). The dimensions used to measure communication about reward systems are adequacy of information, information exchange, supervisor communication and performance feedback. While, the dimensions used to measure participation in performance based reward are two major participation styles: participation in pay design (e.g., start-up stages of pay system) and participation in pay administration (e.g., operation stages of pay system) (Belfield \& Marsden, 2003; Kim, 1996 \& 1999; Lee et al., 1999). Finally, organizational commitment had 5 items adapted from Warr, Cook and Wall's (1979). The dimensions used to measure organizational commitment had 5 items adapted from Warr, Cook and Wall's (1979) organizational commit scale. The dimensions used to measure organizational commitment are the affective commitment subscale developed by Meyer \& Allen (1997). All items used in the questionnaire were measured using a 7-item scale ranging from "strongly disagree/dissatisfied" (1) to "strongly agree/satisfied" (7). Demographic variables were used as controlling variables because this study focused on employee attitudes.

A convenient sampling technique was employed to distribute 2000 survey questionnaires to employees who have worked in non-academic and academic divisions in private tertiary educational institutions in Peninsular Malaysia. This sampling technique was chosen because the list of registered employees was not given to the researchers for confidential reasons and this situation did not allow the researchers to randomly select participants in the organization. Of the number, 299 usable questionnaires were returned to the researchers, yielding 14.95 percent of the response rate. The survey questionnaires were answered by participants based on their consents and a voluntarily basis. The figure exceeds the minimum sample of 30 participants as required by probability sampling technique, showing that it may be analyzed using inferential statistics (Sekaran \& Bougie, 2010).

The SmartPLS 2.0 was employed to assess the validity and reliability of the instrument and thus test the research hypotheses (Henseler et al., 2009; Ringle et al., 2005). The main 
advantage of using this method may deliver latent variable scores, avoid small sample size problems, estimate every complex model with many latent and manifest variables, hassle stringent assumptions about the distribution of variables and error terms, and handle both reflective and formative measurement models (Henseler et al., 2009; Ringle et al., 2005). The SmartPLS path model was employed to assess the path coefficients for the structural model using the standardized beta $(\beta)$ and t statistics. Baron and Kenny (1986) suggest that a mediating variable can be clearly shown in the path model when a previously significant effect of predictor variables is reduced to non-significance or reduced in terms of effect size after the inclusion of mediator variables into the analysis. The value of $\mathrm{R} 2$ is used as an indicator of the overall predictive strength of the model. The value of R2 is considered as follows; 0.19 (weak), 0.33 (moderate) and 0.67 (substantial) (Chin, 1998; Henseler et al., 2009). Thus, a global fit measure is conducted to validate the adequacy of PLS path model globally based on Wetzels et al.'s (2009) global fit measure. If the results of testing hypothesized model exceed the cutoff value of 0.36 for large effect sizes of $\mathrm{R}^{2}$, showing that it adequately supports the PLS path model globally (Wetzels et al., 2009).

\section{FINDINGS}

\section{Respondents' Characteristics}

In term of respondents' characteristics, the majority of respondents were females $(57.2 \%)$, ages vary from 26 to 30 years $(47.8 \%)$, bachelor holders $(47.8 \%)$, lecturers and assistant lecturers $(54.2 \%)$, working in academic divisions $(78.6 \%)$, working experiences from 3 to 5 years $(42.1 \%)$ and monthly salary between RM1000 to $2000(56.9 \%)$.

Confirmatory factor analysis (CFA) was conducted to determine the validity and reliability of the instrument. Table 1 shows the results of convergent and discriminant validity analyses. All concepts had the values of average extracted variance (AVE) larger than 0.5, indicating that they met the acceptable standard of convergent validity (Barclay et al., 1995; Fornell \& Larcker, 1981; Henseler et al., 2009). Besides that, all concepts had the values of $\sqrt{ }$ AVE in diagonal were greater than the squared correlation with other concepts in off diagonal, signifying that all concepts met the acceptable standard of discriminant validity (Henseler et al., 2009; Yang, 2009).

Table 1. The Results of Convergent and Discriminant Validity Analyses.

\begin{tabular}{|c|c|c|c|c|}
\hline Variable & AVE & Communication & Participation & $\begin{array}{c}\text { Organizational } \\
\text { Commitment }\end{array}$ \\
\hline Communication & 0.684497 & 0.824621 & & \\
\hline Participation & 0.674263 & 0.381181 & 0.821135 & \\
\hline $\begin{array}{c}\text { Organizational } \\
\text { Commitment }\end{array}$ & 0.769595 & 0.472762 & 0.287989 & 0.877265 \\
\hline
\end{tabular}

Table 2 shows the factor loadings and cross loadings for different constructs. The correlation between items and factors had higher loadings than other items in the different 
concepts, as well as the loadings of variables were greater than 0.7 in their own constructs in the model are considered adequate (Henseler et al., 2009). In sum, the validity of the measurement model met the criteria.

Table 2 also shows the results of reliability analysis for the instrument. The values of composite reliability and Cronbach's Alpha were greater than 0.8 , indicating that the instrument used in this study had high internal consistency (Henseler et al., 2009; Nunally \& Bernstein, 1994).

Table 2. The Results of Factor Loadings and Cross Loadings for Different Constructs.

\begin{tabular}{|c|c|c|c|c|c|}
\hline Construct/ Item & Communication & Participation & $\begin{array}{c}\text { Job } \\
\text { Satisfaction }\end{array}$ & $\begin{array}{l}\text { Composite } \\
\text { Reliability }\end{array}$ & $\begin{array}{l}\text { Cronbach } \\
\text { Alpha }\end{array}$ \\
\hline$\frac{\text { Communication }}{\text { Com } 1}$ & 0.753676 & & & \multirow[t]{4}{*}{0.896328} & \multirow[t]{4}{*}{0.845214} \\
\hline Com2 & 0.867030 & & & & \\
\hline Com3 & 0.835026 & & & & \\
\hline Com4 & 0.849064 & & & & \\
\hline$\frac{\text { Participation }}{\text { Part1 }}$ & & 0.844522 & & \multirow[t]{5}{*}{0.911660} & \multirow[t]{5}{*}{0.878754} \\
\hline Part2 & & 0.837254 & & & \\
\hline Part3 & & 0.854788 & & & \\
\hline Part4 & & 0.778332 & & & \\
\hline Part5 & & 0.787805 & & & \\
\hline$\frac{\text { Organizational }}{\underline{\text { Commitment }}}$ & & & & \multirow[t]{4}{*}{0.857753} & \multirow[t]{4}{*}{0.754720} \\
\hline Commit1 & & & 0.752850 & & \\
\hline Commit2 & & & 0.821352 & & \\
\hline Commit3 & & & 0.875724 & & \\
\hline
\end{tabular}

\section{Analysis of the Constructs}

Table 3 shows the results of Pearson correlation analysis and descriptive statistics. The means for all variables were from 4.0 to 5.0, signifying that the level of communication about reward systems, participation in reward systems and organizational commitment are ranging from high (3.0) to the highest level (7). The correlation coefficients for the relationship between the independent variable (i.e., communication and participation) and the dependent variable (i.e., organizational commitment) were less than 0.90 , indicating the data were not affected by serious collinearity problem (Hair et al., 1998). Hence, the reliability values for the constructs were 1.0, showing that the constructs had met the standards of reliability analysis. Therefore, these statistical results confirm that the constructs have met the acceptable standards of validity and reliability analyses (Hair et al., 1998; Nunally \& Bernstein, 1994). Thus, these statistical results provide further evidence of validity and reliability for the constructs used in this study. 
Table 3. Pearson Correlation Analysis and Descriptive Statistics.

\begin{tabular}{|c|c|c|c|c|c|}
\hline Variables & Mean & $\begin{array}{c}\text { Standard } \\
\text { Deviation }\end{array}$ & \multicolumn{3}{|c|}{ Pearson Correlation (r) } \\
\hline & & & 1 & 2 & 3 \\
\hline Communication & 4.2 & 1.3 & 1 & & \\
\hline Participation & 4.0 & 1.3 & $0.38^{* *}$ & 1 & \\
\hline Organizational Commitment & 5.0 & 1.0 & $0.46^{* *}$ & $0.28^{* *}$ & 1 \\
\hline
\end{tabular}

Note: Significant at $* * p<0.01$

Figure 2 presents the outcomes of testing a mediating model using SmartPLS. It showed that the inclusion of communication about reward systems, participation in reward systems and organizational commitment in the analysis had explained 24 percent of the variance in dependent variable. Specifically, the result of SmartPLS path analysis revealed two important findings: first, communication about performance related reward positively and significantly correlated with organizational commitment $(\beta=0.43 ; \mathrm{t}=6.37)$, therefore H1 was supported. Second, participation in performance related reward positively and significantly correlated with organizational commitment $(\beta=0.13 ; \mathrm{t}=1.97)$, therefore $\mathrm{H} 2$ was supported. In sum, the result confirms that the administration of performance based reward as an important predictor of organizational commitment in the hypothesized model.

Administration System and Organizational Commitment.

Independent Variable

Dependent Variable

$\mathrm{R}^{2}=0.24$

\begin{tabular}{|c|c|c|}
\hline Communication & $\mathrm{B}=0.43 ; \mathrm{t}=6.37$ & $\begin{array}{c}\text { Organizational } \\
\text { Commitment }\end{array}$ \\
\cline { 2 - 3 } & $\mathrm{B}=0.13 ; \mathrm{t}=1.97$ & \\
\hline
\end{tabular}

Note: Significant at $* \mathrm{t}>1.96$

Figure 2. The Outcomes of SmartPLS Path Model Showing the Relationship between Reward.

In order to determine a global fit PLS path model, we carried out a global fit measure (GoF) based on Wetzel's et al.'s (2009) guideline as follows: GoF=SQRT \{MEAN (Communality of Endogenous) $x$ MEAN $\left.\left(\mathrm{R}^{2}\right)\right\}=0.24$, indicating that it exceeds the cutoff value of 0.36 for large effect sizes of $\mathrm{R}^{2}$. This result confirms that the PLS path model has better explaining power in comparison with the baseline values (GoF small=0.1, GoF medium $=0.25$, GoF large $=0.36$ ). It provides strong support to validate the PLS model globally (Wetzels et al., 2009). 


\section{DISCUSSION}

The findings of this study confirm that the reward administration system does act as an important predictor of organizational commitment in the studied organization. In the context of this study, managers have used compensation policies and rules set up by the stakeholders to determine the type, level and/or amount of reward for high performing employees. Majority employees perceive that the level of communication about reward systems, participation in reward systems and organizational commitment are high. In this condition, majority employees judge that the ability of administrators to openly communicate the information about reward systems, and actively implement participation in reward systems has led to enhanced organizational commitment.

This study provides three important implications: theoretical contribution, robustness of research methodology and practical contribution. With respect to theoretical contribution, this study highlights two major findings, firstly, communication about reward systems has been an important predictor of organizational commitment. Secondly, participation in reward systems has been an important predictor of organizational commitment. This finding is supported and disseminated the recommendations of the Quran, the Prophet Muhammad PBUH and commendable practicesndertaken by contemporary researchers like Mignery et al. (1995), O'Malley (2000), Hafer and Martin (2006), Sharan and Garib (2009), and Zeeshan et al. (2010). The finding of this study advocated that the relationship between reward administration system and organizational commitment was significant but the impact factor of reward administration system and organizational commitment was low. A thorough review of the interview result shows that this result may be affected by external factors which are different profile of respondents' characteristics and different management skills towards managing reward asministration system in the studied organizations.

In terms of the robustness of research methodology, the finding of this study may be used by administrators to improve the management of reward systems in organizations. This improvement should be done in the following scopes: This is recommended for the management and employees of the organization, firstly, the extra rewards for high performers can be perceived more valuable if the type, level and/or amount of pay are revised according to the current national cost of living and organizational changes. This may help them to give more focus on achieving organizational goals because they view that extra rewards fulfill their expectations, standards of living and statuses in society. Secondly, the content and method of management development programs need to emphasize on creative soft skills (e.g., stimulate employees' intellectuals) in doing a job, respect employees' voices, counsel employees to increase their potentials to achieve better career, learn new problem solving skills approach and share the organizational interests) may upgrade the ability of managers to practice good interaction styles in managing reward administration system. Finally, Islamic ethical values like believe to Allah SWT, doing the right things, being a good example to others, and fulfil employees' welfare and rights should be inculcated in order to enhance employees' feelings of justice (Ali, 2005; Rizk, 2008). If organizations heavily consider these suggestions, this may highly encourage employees to support and respect the workplace reward system goals and procedures. 


\section{CONCLUSION}

This study proposed a conceptual framework based on the reward administration system research literature. The instrument used in this study met the acceptable standards of validity and reliability analyses. The outcomes of SmartPLS path analysis confirmed that the reward administration system (i.e., communication and participation) did act as an important predictor of organizational commitment in the organizational sample. This result has also supported and broadened reward administration system literature, mostly published in Western countries. Therefore, current research and practice within the reward administration program model needs to consider communication and participation as a critical success factor of the reward administration system.

\section{References}

\section{[1] Al-Quran}

[2] Appelbaum, S.H., \& Mackenzie, L. (2000). Compensation in the year 2000: Performance based reward Health Manpower Management, 22 (3): 31-39.

[3] Belfield, R., \& Marsden, D. (2003). Performance pay, monitoring environments, and establishment performance. International Journal of Manpower, 24 (4): 452-471.

[4] Bergmann, T.J., \& Scarpello, V.G. (2002). Compensation decision making. United States: South-Western Thomson Learning.

[5] Bies, R.J., Sharpiro, D.L., \& Cummings, L.L. (1988). Causal accounts and managing organizational conflict: is it enough to say it's not my fault? Communication Research, 15: 381-399.

[6] Chang, E., \& Hahn, J. (2006). Does pay-for-performance enhance perceived distributive justice for collectivistics employees? Personnel Review, 35 (4): 397-412.

[7] Cook, T.D. and Campbell, D.T. (1979). Quasi-Experimentation: Design and Analysis for Field Settings. Rand McNally, Chicago, Illinois.

[8] Coyle-Shapiro, J.A-M., Morrow, P.C., Richardson, R., \& Dunn, S.R. (2002). Using profit sharing to enhance employee attitudes: A longitudinal examination of the effects on trust and commitment. Human Resource Management, 41 (4): 423-439.

[9] Cresswell, J.W. (2014). Qualitative inquiry and research design: Choosing among five traditions. London: SAGE publications.

[10] Cropanzano, R., Byrne, Z. S., Bobocel, D. R., \& Rupp, D. R. (2001). Moral virtues, fairness heuristics, social entities, and other denizens of organizational justice. Journal of Vocational Behavior, 58: 164-209.

[11] Folger, R., Konovsky, M.A., \& Cropanzano, R. (1992). A due process metaphor for performance appraisal. Research in Organizational Behavior, 3: 129-177.

[12] Foster, D.P., Stine, B., \& Waterman, R. (1998). Business analysis using regression: A casebook.US: Springer-Verlag.

[13] Gomez-Mejia, L.R. \& Balkin, D.B. (1992a). Compensation, organizational strategy, and firm performance. Cincinnati, $\mathrm{OH}$ : South Western Publishing Co. 
[14] Gomez-Mejia, L.R. \& Balkin, D.B. (1992b). The determinants of faculty pay: An agency theory perspective. Academy of Management Journal, 35 (5): 921-955.

[15] Greenberg, J. (2003). Creating unfairness by mandating fair procedures: The hidden words of a pay-for-performance plan. Human Resource Management Review, 13: 41-57.

[16] Henderson, R.I. (2009). Compensation management in a knowledge based-world. New Jersey: Prentice-Hall.

[17] Ismail, I., Hock, W.K., \& Sulaiman, S. (2007). Relationship between Performance based reward Features and Job Satisfaction: Does Interactional Justice Act as a Mediating Role? The seventh AAM International Conference, 2,495-503, May 22-24, 2007, Science University of Malaysia, Penang, Malaysia.

[18] Ismail, A., Guatleng, O., Cheeking, T., Ibrahim, Z., Ajis, M.N., \& Dollah, N.F. (2009).The indirect effect of distributive justice in the relationship between pay structure and work attitudes and behavior. European Journal of Social Sciences, 11 (2): 234-248.

[19] John C. Hafer \& Thomas N. Martin (2006). Job involvement or affective commitment: A sensitivity analysis study of apathetic employee mobility. Institute of Behavirol and Applied Management.

[20] Kamus Dewan. (2005). 4th ed. Kuala Lumpur: Dewan Bahasa dan Pustaka.

[21] Lawler, E.D. (2000). Rewarding Excellence: Pay Strategies for the New Economy. California: Jossey-Bass.

[22] Lawler, E.E. (1995). Choosing an involvement strategy. Academy of Management Executive, 2: 197-203.

[23] Lawler, E.E., Ledford, G., \& Chang, L. (1993). Who uses skill-based pay, and why. Compensation and Benefits Review, March-April: 22-26.

[24] Lee, C., Law, K.S., \& Bobko, P. (1999). The importance of justice perceptions on pay effectiveness: A two-year study of a skill-based pay plan. Journal of Management, 25 (6): 851-873.

[25] McCausland, W.D., Pouliakas, K. \& Theodossiou, I. (2005). Some are punished and some are rewarded. A study of the impact of performance pays on job satisfaction. International Journal of Manpower, 26 (7/8): 636-659.

[26] McShane, S.L. \& Von Glinow, M.A. (2005).Organizational Behavior. Irwin: McGrawHill.

[27] Milkovich, G.T. \& Newman J.M. (2014). Compensation. New York: McGraw Hill.

[28] Money, R.B., \& Graham, J.L. (1999). Salesperson performance, pay and job satisfaction: Test of a model using data collected in the United States and Japan. Journal of International Business Studies, 30: 149-172.

[29] Nunally, J.C., \& Bernstein, I.H. (1994).Psychometric theory. New York: McGraw- Hill.

[30] O’Malley, M. (2000). Creating commitment. John Wiley \& Sons. Chichester.

[31] Oxford Dictionary of Islam, (2004).

[32] Oxford Engish Dictionary, (2007). 
[33] Pettijohn, C.E., Pettijohn, L.S., \& d'Amico, M. (2001). Charateristics of performance appraisals and their impact on sales force satisfaction. Human Resource Development Quarterly, 12 (2): 127-146.

[34] Sekaran, U. (2000). Research methods for business: A skill building approach. New York: John Wiley \& Sons, Inc.

[35] Shaw, J.D., Duffy, M.K., Jenkins, G.D., \& Gupta,, N. (1999). Positive and negative affect, signal sensitivity, and pay satisfaction. Journal of Management, 25 (2): 189-206.

[36] Sharon Kaur \& Garib Singh (2009). A study on employee participation in decision making. Unitar e-journal, 5(1)

[37] Skarlicki, D. P., \& Folger, R. (1997). Retaliation in the workplace: The roles of distributive, procedural and interactional justice. Journal of Applied Psychology, 82: 434-443.

[38] The Quran. (1997). Arabic Text with Corresponding English Meanings, Riyadh, Abulqasim Publishing House.

[39] Vroom, V.H. (1964). Work and Motivation. San Francisco, CA: Jossey-Bass.

[40] Warr, P.B., Cook, J. \& Wall, T.D. (1979). Scales for the Measurement of Some Work Attitudes and Aspects of Psychological Well-Being. Journal of Occupational Psychology, 52: 129-148.

[41] Wetzels, M., Oderkerken-Schroder, G. \& Van Oppen, C. (2009). Using PLS Path Modelling for Assesssing Hierchical Construct Models: Guidance and Empirical Illustration. Management Information System (MIS) Quarterly, 33(1): 177-195.

[42] Zeeshan Khan, Hina Ali, Nadeem Ehsan \& Ebtisam Mirza (2010). Impact of goal clarity on organizational commitment in telecommunication organizations of Pakistan. 